\title{
DUGAAN TINDAK PIDANA KORUPSI DALAM PENGADAAN TANAH UNTUK KEPENTINGAN UMUM
}

\author{
Aartje Tehupeiory ${ }^{*}$
}

\begin{abstract}
In terms of the provision of land for the public interest was formed the Committee for Land Procurement (P2T) based on the number of Presidential Decree No. 55 of 1993, with one of the principle is not looking for profit. Based on that, the Governor of Maluku made a decree on the city of Ambon in the decree for the construction of a common or garden Burial Tombs common (TPU). Because of thesituation/circumstances of the civil emergency in the province of Maluku, at the discretion of the Mayor of Ambon city as the Executive ruler of the elements of the civil emergency, delegated various tasks to the team's who had the responsibility to carry out the release of P2T land rights.But later in the day, a problem occurs that is alleged to have elements of criminal acts of corruption in the procurement of land for the public interest with respect to the construction of TPU. While all of the procedures and the mechanism of release of land rights has been carried out in accordance with Presidential Decree No. 55 no 1993. This is because the Government cannot took over the land purchase benefits.Therefore there needs to be re-construction (reconstruction) of losses the country associated with the procurement of land for the public interest.
\end{abstract}

\section{Kata kunci: Dugaan tindak pidana korupsi pengadaan tanah}

\section{Pendahuluan}

Tidak ada pembangunan tanpa tanah. Jika tidak tersedia tanah yang cukup untuk pembangunan, maka usaha-usaha pembangunan akan macet. ${ }^{1}$ Salah satu cara untuk memenuhi kebutuhan akan tanah guna melaksanakan pembangunan adalah dengan pengadaan tanah. Pada prakteknya, masalah tersebut ditempuh Negara ketika perbuatan hukum keperdataan mengalami kebuntuan. Tindakan Negara untuk memperoleh tanah untuk berbagai kegiatan pembangunan khususnya bagi kepentingan umum dengan cara pengadaan tanah. Pada prinsipnya dilakukan dengan musyawarah antara pihak yang memerlukan tanah dan pemegang hak atas tanah yang diperlukan untuk kegiatan pembangunan. $^{2}$

Secara konstitusional, dasar pengadaan tanah untuk kepentingan umum oleh pemerintah diatur dalam Pasal 33 ayat (3) UUD 1945, bahwa semua tanah yang berada di wilayah Republik Indonesia dikuasai oleh negara dan negara dapat menetapkan bidang-bidang tanah tersebut untuk dipunyai dan dimiliki oleh war-

\footnotetext{
${ }^{*)}$ Dosen Tetap Fakultas Hukum UKI Jakarta

${ }^{1}$ Aartje Tehupeinory, "Pembebasan Tanah KBT", Suara Pembaruan, 29 Desember 2009, hal. 6

${ }^{2}$ Maria S.W. Sumardjono, Tanah dalam perspektif hak ekonomi, sosial, budaya. Jakarta: Kompas, 2008, Cet. Pertama, hal. 280
}

ga negaranya dengan sesuatu hak. Pemberian hak oleh negara kepada warga negaranya ditetapkan dalam suatu penetapan pemerintah (beschikking) suatu bukti hukum bagi rakyat yang bersangkutan adalah pemilik tanah, dan karena itu berhak mendapat perlindungan. ${ }^{3}$

Berkaitan dengan hal diatas maka pemerintah dalam melaksanakan pembangunan mempunyai kewajiban untuk menyediakan tanah yang diperlukan untuk pembangunan. Dikenal (3) macam status tanah, yaitu: Tanah Negara adalah tanah yang langsung dikuasai oleh Negara. Selanjutnya tanah hak adalah tanah yang dipunyai oleh perorangan atau badan hukum, artinya sudah terdapat hubungan hukum yang konkrit antara subjek tertentu dengan tanahnya. Terakhir tanah ulayat adalah tanah dalam penguasaan suatu masyarakat hukum adat. Jelaslah bahwa pemerintah dalam menyediakan tanah untuk pembangunan mengambil tanah yang berasal dari tanah Negara yang tidak dikuasai oleh rakyat bagi kepentingan pembangunan. Namun pemerintah tidak mampu menyediakan tanah untuk memenuhi semua kebutuhan pembangunan sehingga banyak proyek pembangunan yang dilakukan ha-

\footnotetext{
$\overline{3}$ Gunanegara, rakyat dan negara dalam pengadaan tanah untuk pembangunan, Jakarta: Tata Nusa, 2008, Cetakan Pertama, hal. 15.
} 
rus mengambil tanah rakyat.

Dalam rangka melindungi hak-hak rakyat dari penguasa, dengan bersumber pada UUPA Nomor 5 tahun 1960 dibuat perangkat ketentuan-ketentuan yang mengatur tentang bagaimana penguasa dapat menguasai tanah yang diperlukan apabila tanah tersebut dikuasai rakyat. Ketentuan-ketentuan itu adalah ketentuan-ketentuan tentang pembebasan atau pelepasan hak atas tanah.

Jika penguasa ataupun pengusaha serta kalangan bisnis memerlukan tanah untuk keperluan apapun, maka pada asasnya cara untuk memperoleh yang diperlukan untuk melaksanakan pembangunan harus melalui jalan musyawarah antara pihak yang memerlukan tanah dengan pemegang hak atas tanah hingga dicapai suatu kesepakatan antara kedua belah pihak. Namun dari sekian banyaknya masalah tanah yang terjadi, yang paling sering dirasakan oleh masyarakat adalah masalah pembebasan tanah atau pelepasan tanah khususnya untuk kepentingan pembangunan. Dan biasanya, jika ditelusuri masalahnya berkisar pada masalah ketidak sepakatan antara para pihak dalam menentukan besarnya ganti kekerugianan.

\section{Permasalahan}

1. Bagaimana tanggungjawab hukum panitia pengadaan tanah untuk kepentingan umum?

2. Apakah pengadaan tanah untuk kepentingan umum dapat dikualifikasikan sebagai tindak pidana korupsi?

\section{Tujuan Penulisan}

1. Untuk mengetahui tanggung jawab hukum panitia pengadaan tanah untuk kepentingan umum.

2. Untuk mengetahui apakah pengadaan tanah untuk kepentingan umum dapat dikualifikasikan sebagai tindak pidana korupsi.

\section{Pengadaan tanah untuk kepentingan umum}

Dalam hal pengadaan tanah untuk kepentingan umum dalam praktek pelaksanaan secara khusus di daerah gunung nona dan sekitarnya (kota Ambon provinsi Maluku) khususnya dalam hal pengadaan tanah untuk kepentingan perkuburan umum (TPU) proses dan tata cara pelepasan tanah sudah dilaksanakan sesuai dengan ketentuan yang diatur dalam
Keputusan Presiden Nomor 55 Tahun 1993 tentang pengadaan tanah bagi pelaksanaan pembangunan untuk kepentingan umum. Di kemudian hari terjadi masalah yang diduga telah terjadi penyimpangan atas pengadaan tanah untuk lokasi TPU. Terjadinya dugaan penyimpangan atas pengadaan tanah untuk lokasi TPU bermula pada saat pemerintah kota mengajukan pengadaan tanah untuk TPU kepada DPRD perihal "Pengadaan Tanah Untuk Perkuburan Umum dan Ganti Kerugian Tanah Pasar Passo" yang dikeluarkan oleh Walikota. Bahwa tanah TPU di Kelurahan Benteng yang sudah tidak mungkin lagi untuk pemakaman jenazah pada waktu-waktu mendatang. Maka Pemerintah bermaksud untuk membeli tanah milik rakyat yang telah bersertifikat maupun yang masih berstatus tanah negara-tanah adat yang belum dikonversi menjadi suatu hak sebagaimana diatur di dalam UUPA.

Berdasarkan hal tersebut diatas dibentuk Panitia pengadaan tanah untuk kepentingan umum kota berdasarkan Surat Keputusan Gubernur dengan susunan kepanitiaan sesuai SK Gubernur yang terdiri dari Ketua; Walikota exofficio, Wakil Walikota; Kepala Kantor Pertanahan Kota, Sekretaris; Asisten 1 Tata Pemerintahan Sekretariat Kota, Wakil Sekretaris; Kepala Seksi hak-hak Atas Tanah pada Kantor Pertanahan Kota, Anggota; Perwakilan Kantor Pelayanan Pajak Bumi dan Bangunan, Kepala Dinas Pekerjaan Umum Kota, Kepala Dinas Pertanian Kota, Camat \& Kepala Desa/Lurah lokasi lahan yang akan dibebaskan. ${ }^{4}$

Dengan diterbitkan Keputusan Presiden Nomor 55 Tahun 1993 (Keppres Nomor 55/ 1993) tentang pengadaan tanah bagi pelaksanaan pembangunan untuk kepentingan umum maka pembangunan TPU saat itu tahun 2003 masih berlaku Keppres Nomor 55/1993, maka semua pengambil alihan tanah untuk kepentingan umum dilakukan berdasarkan peraturan ini, yang pelaksanaannya ditunjang dengan peraturan Menteri Negara Agraria/Kepala Badan Pertanahan Nasional Nomor 1 Tahun 1994 (selanjutnya disebut PMNA/Ka BPN Nomor 1 Tahun 1994). Berdasarkan ketentuan ini pemerintah kotamadya mengajukan pengadaan ta-

\footnotetext{
${ }^{4}$ Hasil wawancara dengan informan selaku ketua panitia pengadaan tanah, 1 September 2014, yang diduga melakukan tindak pidana korupsi pengadaan tanah TPU.
} 
nah untuk perkuburan umum, bahwa tanah perkuburan umum dikelurahan Benteng tidak mungkin lagi untuk pemakanan jenazah pada waktu-waktu mendatang, maka pemerintah kota Ambon bermaksud untuk melakukan pembangunan kembali TPU tersebut dilokasi yang berbeda yaitu Gunung Nona dan sekitarnya. ${ }^{5}$ Kemudian pemerintah bermaksud membeli tanah-tanah milik masyarakat baik yang berstatus bersertifikat dan masih berstatus tanah hak adat yang belum dikonversi menjadi suatu hak sebagaimana diatur dalam UUPA Nomor 5 Tahun 1960. Selanjutnya dikeluarkan "Permohonan penawaran pengadaan tanah tempat perkuburan (TPU) kota Ambon". Oleh masyarakat desa yang berada disekitar batas-batas petuanan desa lokasi yang akan dibangun TPU tersebut.

Pada saat itu di kota terjadi keadaan darurat sipil di propinsi Maluku dan propinsi Maluku Utara. Selaku ketua, walikota ex-officio yang didukung oleh DPRD Kota, ditetapkan alokasi anggarannya dalam APBD perubahan tahun 2003 untuk Pos Pengadaan tanah untuk TPU dengan proses dan tatacara sebagaimana yang diatur dalam Keppres Nomor 55/1993. Selaku Walikota dan unsur pelaksana darurat sipil di kota mengumumkan berkalikali di berbagai media masa (cetak dan elektronik) tentang rencana pemerintah melakukan pengadaan tanah untuk membangun TPU hal ini dilakukan dengan tujuan: "agar masyarakat mengetahui bahwa pemerintah sedang memikirkan kepentingan masyarakat, agar masyarakat yang memiliki tanah seluas 5 Ha dapat mengajukan penawaran kepada pemerintah kota. Pada akhirnya ada pemilik tanah yang mengajukan penawaran tanahnya kemudian Panitia Pengadaan Tanah (P2T) melakukan peninjauan di lapangan dengan mengadakan penelitian dan pengecekan atas status penguasaan tanah yang dimiliki oleh masyarakat. Setelah diadakan proses pelepasan tanah yang dilakukan dengan cara musyawarah dan ganti kerugian tanah masyarakat yang melepaskan tanahnya untuk pembangunan TPU Gunung Nona. Seluruh tahapan proses teknis pengadaan tanah dilaksanakan sampai selesai, dengan menyerahkan dokumen-dokumen yang telah disepekati antara P2T dan pemilik tanah berupa surat pernya-

\footnotetext{
${ }^{5}$ Ibid.
}

taan kesepakatan surat pernyataan pelepasan hak. Berita acara penyaksian pelepasan hak dan berita acara penyaksian pembayaran ganti kerugian, maka berdasarkan dokumen yang berisikan harga beli tanah yang disepakati, selaku ketua P2T, ex-officio menandatangani dari seluruh proses pengadaan tanah diselesaikan pada tahap selanjutnya, termasuk pembayaran ganti kerugian kepada pemilik tanah dan biaya-biaya lain serta pajak, yang keseluruhannya dari anggaran yang disediakan dalam APBD Kota tahun 2003. ${ }^{6}$

Tahun 2013 terjadi klaim dari masyarakat adat yang menyatakan bahwa tanah yang dilepaskan untuk pembangunan TPU kepada P2T merupakan bagian dari sengketa perdata yang terjadi antara kedua masyarakat adat yang ada disekitar lokasi pembangunan TPU. Namun berdasarkan Surat Ketua Pengadilan Negeri Nomor W18.D.AB.HT.04.10.128 perihal; "mohon penjelasan hukum, menyatakan bahwa, Putusan Mahkamah Agung Republik Indonesia Nomor 3168K/Pdt,1990" tersebut

(i) tidak dapat dieksekusi karena diktum putusan tidak ada yang bersifat comdemnatoir (hukuman) hanya bersifat konstitutif dan declaratoir, dan menyatakan anggota masyarakat yang melepaskan tanahnya untuk pembangunan TPU kepada P2T adalah bukan pihak terhadap sengketa kepemilikan tanah yang terjadi antara kedua masyarakat adat tersebut.

Berdasarkan paparan penjelasan diatas maka selaku ketua P2T ex-officio dan wakil ketua P2T oleh penyidik propinsi diperiksa sebagai tersangka dalam perkara dugaan tindak pidana korupsi pengadaan tanah untuk TPU. Dengan alasan bahwa pemerintah kota tidak bisa mengambil manfaat atas pembelian tanah tersebut, karena tanah tersebut belum tercatat sebagai asset daerah dan proyek pembangunan TPU belum terlaksana.

Dalam memenuhi kebutuhan tanah untuk pembangunan semula dikenal adanya pembebasan tanah untuk keperluan pemerintah ${ }^{7}$ dan

\footnotetext{
${ }^{6}$ Ibid.

${ }^{7}$ Diatur dengan Peraturan Menteri Dalam Negeri nomor 15 tahun 1975 yang merupakan ketentuan intern Pemerintah dalam pengamanan kekayaan negara, baik yang berhubungan dengan penentuan bentuk dan besarnya ganti kerugian maupun mengenai pertanggungjawaban keuangan negara. Dan peraturan menteri dalam negeri nomor 2 tahun 1985 yang mengatur
} 
pembebasan tanah untuk keperluan swasta, ${ }^{8}$ yang pada dasarnya sama-sama harus didasarkan kepada ketentuan musyawarah, dan pengawasan pelaksanaannya dilakukan oleh Bupati/ Walikotamadya Kepala Daerah Tingkat II. Selanjutnya dalam acara pembebasan tanah atau pelepasan tanah ditempuh jika suatu pihak yang bermaksud memperoleh dan menguasai sebidang tanah tertentu yang berstatus Hak Milik ataupun bekas Hak Milik Adat, sedangkan ia sendiri tidak memenuhi syarat untuk dapat menguasai tanah tersebut dan untuk mengalihkan Hak Milik itu langsung kepadanya akan mengakibatkan berlakunya ketentuan pasal 26 ayat (2) UUPA, yaitu perbuatan hukumnya batal demi hukum, tanahnya jatuh pada negara dan uang yang sudah dibayarkan tidak dapat dikembalikan. Dengan cara membebaskan tanah milik Hak Milik tersebut, maka tanahnya kemudian menjadi tanah negara dan pihak yang membebaskan kemudian dapat mengajukan permohonan hak baru yang sesuai dengan peruntukan tanahnya. Acara pembebasan tanah ini juga dilakukan bila suatu instansi pemerintah atau badan hukum kepunyaan negara/swasta memerlukan areal tanah yang luas untuk usaha-usaha pembangunan terutama untuk kepentingan umum.

\section{Kepentingan Umum}

Kegiatan pembangunan untuk kepentingan umum dibatasi dengan ketentuan yang pada prinsipnya membuat 3 unsur pokok, yaitu;

a) Merupakan kegiatan pembangunan yang dilakukan oleh pemerintah;

b) Selanjutnya dimiliki oleh pemerintah;

mengenai tata cara pengadaan tanah untuk keperluan proyek pembangunan di wilayah kecamatan.

${ }^{8}$ Semula untuk swasta hanya dapat melakukan pembebasan tanah secara langsung dengan pe-megang hak atas tanah. Kemudian atas dasar pertimbangan bahwa pelaksanaan pembangunan tidak semata-mata menjadi beban pemerintah, dan untuk merangsang pihak swasta dalam pelaksanaan pembangunan, dipandang perlu adanya bantuan fasilitas dari pemerintah berbentuk jasa-jasa dalam pembebasan tanah rakyat untuk pembangunan proyek-proyek yang bersifat menunjang kepentingan umum atau termasuk dalam bidang pembangunan saran umum dan fasilitas-fasilitas sosial. Maka ditetapkan Peraturan Menteri Dalam Negeri nomor 2 tahun 1976 tentang Penggunaan Acara Pembebasan Tanah untuk kepentingan pemerintah bagi pembebasan tanah oleh pihak swasta. c) Serta tidak digunakan untuk mencari keuntungan.

Maria S.W. Soemardjono berpendapat bahwa pengertian kepentingan umum dalam pasal 5 angka 1 Keppres 55/1993 tersebut menganut pendekatan yang sempit dengan memberikan definisi yang ketat tentang kepentingan umum, diikuti dengan 14 contoh kegiatan yang tidak membuka penafsiran lebih lanjut. ${ }^{9}$ Penafsiran yang ketat tersebut diharapkan dapat memberikan keadilan dan kepastian hukum, karena merugikan para pemegang hak. ${ }^{10}$

Berdasarkan hal tersebut diatas pengadaan tanah untuk perkuburan umum dilokasi Gunung Nona dan sekitarnya dapat dikategorikan sebagai bentuk kegiatan pembangunan yang memenuhi 3 unsur pokok tersebut diatas. Oleh karenanya kepentingan umum dapat didefinisikan sebagai kepentingan yang menyangkut hajat orang banyak, berfungsi melayani dan memenuhi kebutuhan masyarakat dimana hal-hal mengenai fungsi, kontrol, tarif, pembagian keuntungan dan kepemilikannya diatur dengan peraturan daerah dan DPRD yang bersangkutan dengan bermanfaat bagi masyarakat sesuai dengan proses sebagaimana semestinya dengan berpatokan pada rencana tata ruang yang telah disahkan sesuai ketentuan yang berlaku. Selain itu melalui proses musyawarah bersama masyarakat untuk membahas berbagai dampak positif dan negatif yang mungkin timbul akibat pembangunan tersebut dapat dicari solusi upaya pendekatan dengan berbagai pihak yang terkait. Pemilihan lokasi Gunung Nona tentunya telah melalui pengkajian teknis, ekonomi, sosial budaya yang menyimpulkan bahwa pembangunan itu memang harus ditempatkan pada lokasi tersebut dan tidak ada lokasi lain yang memadai.

\footnotetext{
${ }^{9}$ Maria S.W. Sumardjono, "Tinjauan Yuridis Keppres No. 55 tahun 1993 tentang pengadaan tanah bagi pelaksanaan pembangunan untuk kepentingan umum dan pelaksanaannya", makalah disampaikan pada seminar nasional "Pengadaan tanah untuk pembangunan" (Konsep hukum, permasalahan dan kebijaksanaan dalam penecahannya), 3 Desember 1994.

${ }^{10}$ Maria S.W. Sumardjono, "Aspek kepentingan umum dalam kaitannya dengan pengadaan tanah", makalah disampaikan dalam seminar "Aspek kepentingan umum dan ganti kerugian dalam kaitannya dengan penggunaan tanah", diselenggarakan oleh mahasiswa Fakultas Hukum UGM, Yogyakarta, 28 September 1991. Dikutip dari Arie S. Hutagalung, SH.MLI "Tebaran Pemikiran Seputar Masalah Hukum Tanah"
} 


\section{Tugas dan Kewenangan Panitia Pengadaan Tanah}

Dalam melaksanakan tugasnya P2T berpedoman pada ketentuan yang diatur di dalam Keppres Nomor 55/1993, diantaranya;

a) Menaksir dan mengusulkan besarnya ganti kerugian atas tanah yang hak atasnya akan dilepaskan atau diserahkan;

b) Memberikan penjelasan atau penyuluhan kepada pemegang hak atas tanah mengenai rencana dan tujuan pengadaan tanah tersebut;

c) Mengadakan musyawarah dengan pemegang hak atas tanah dan Instansi pemerintah yang memerlukan tanah dalam rangka menetapkan bentuk dan/atau besarnya ganti kerugian.

Selain itu, bertugas juga; a) mengadakan survai dasar, survai sosial ekonomi dan inventarisasi dalam rangka kegiatan pengadaan tanah; b) membuat rencana kerja pengadaan tanah, pemukiman kembali dan pembinaan (RKPTKP); c) memberikan laporan tertulis bulanan mengenai pelaksanaan RK-PTKP kepada Bupati/walikotamadya kepala daerah tingkat II melalui panitia pengawas pengadaan tanah; d) mengadakan penyuluhan dan konsultasi kepada masyarakat yang terkena pembangunan mengenai rencana dan tujuan pengadaan tanah; e) menyiapkan dan menandatangani berita acara mengenai bentuk dan besarnya kompensasi; f) menyiapkan dan menandatangani berita acara pelepasan atau penyerahan hak atas tanah; g) menyiapkan berkas dokumen pengadaan tanah untuk setiap bidang tanah untuk diserahkan kepada pihak yang memerlukan tanah untuk keperluan permohonan dan pendaftaran hak; $h$ ) melakukan dan memonitor kegiatan pemukiman kembali dan pembinaan; i) melakukan konsultasi kepada panitia pengawas pengadaan tanah dalam 1 x 1 minggu.

Berakhirnya tugas dan kewenangan P2T setelah terjadi pelepasan hak dan pembebasan atau penyerahan hak dari pemegang hak atas tanah dengan pemberian ganti kerugian. Kemudian dilanjutkan dengan membuat berita acara ganti kerugian dengan saksi-saksi dan juga saksi dalam hal ini anggota dari panitia pengadaan tanah. Itu selesai, kemudian dilanjutkan dengan diserahkan kepada instansi yang memerlukan tanah. Setelah itu tanggung jawab beralih kepada instansi yang memerlukan ta- nah untuk melakukan penguasaan dan pemeliharaan tanah yang telah diganti kerugian. Dengan demikian kewenangan P2T kota propinsi Maluku sudah melaksanakan sesuai dengan ketentuan yang diatur dalam Keppres Nomor 55/1993 artinya tanggung jawab P2T sampai pada pelepasan dan penyerahan hak atas tanah kepada instansi yang memerlukan tanah.

\section{Merugikan Keuangan Negara}

Jika dikaitkan dengan Undang-Undang RI Nomor 31 Tahun 1999 tentang pemberantasan tindak pidana korupsi jo Undang-Undang RI Nomor 20 Tahun 2001 tentang perubahan atas Undang-Undang RI Nomor 31 Tahun 1999 tentang pemberatasan tindak pidana korupsi yang dimaksud setiap orang adalah pegawai negeri atau penyelenggara negara. Menurut pendapat $\mathrm{R}$. Wiyono merugikan adalah sama artinya dengan menjadi kerugian atau menjadi berkurang, sehingga dengan demikian yang dimaksudkan dengan unsur merugikan keuangan negara adalah sama artinya dengan menjadi kerugiannya keuangan negara atau berkurangnya keuangan negara. ${ }^{11}$ Dengan demikian kerugian keuangan negara adalah seluruh kekayaan negara dalam bentuk apapun yang dipisahkan atau yang tidak dipisahkan termasuk di dalamnya segala bagian kekayaan negara dan segala hak dan kewajiban yang timbul karena: a) berada dalam penguasaan, pengurusan, dan pertanggung jawaban pejabat lembaga negara, baik tingkat pusat maupun di daerah; b) berada dalam penguasaan, pengurusan dan pertanggungjawaban badan usaha milik negara/badan usaha milik daerah, yayasan, badan hukum dan perusahaan yang menyertakan modal negara, atau perusahaan yang menyertakan modal pihak ketiga berdasarkan perjanjian dengan negara.

Keterkaitan tanggung jawab P2T selaku ketua walikota ex-officio pada pengadaan tanah untuk TPU yang terletak di daerah $\mathrm{Gu}$ nung Nona dan sekitarnya, jika dikaitkan dengan tindak pidana korupsi penulis berpendapat dikembalikan kepada pertanggungjawaban pidana secara umum, bahwa pertanggungjawaban pidana itu bersifat individual. Korelasi dengan asas dalam hukum pidana Geen Straf

\footnotetext{
${ }^{11}$ R. Wiyono, Pembahasan Undang-Undang RI Pemberantasan Tindak Pidana Korupsi, Jakarta: Sinar Grafika, 2005, hal. 38.
} 
Zonden Schuld, bahwa tiada pidana tanpa kesalahan dengan pembuktian dapat dilihat siapa diantara P2T ini yang sebetulnya memiliki/sikap batin jahat atau mens rea yang menentukan sehingga terjadi penyimpangan. Apakah dalam mekanisme pelaporan atau pendataan yang seharusnya dilakukan dalam bentuk tanggung jawab kepanitiaan (pertanggungjawaban kolektif). Jika keanggotaan melakukan perbuatan melawan hukum maka walikota sebagai kepala daerah ex-officio ketua panitia. Maka ketua panitia jika sudah menentukan orang tertentu untuk melakukan telaah penelitian tadi, maka orang itulah yang seharusnya juga memberikan laporan pertanggungjawaban sebagaimana mestinya. Bukan kepala daerah yang memberikan pertanggungjawaban. Karena itu menyangkut motif maka hal tersebut berkaitan dengan psikologis dan harus dikaitkan dengan persoalan-persoalan apakah dia nantinya akan diuntungkan dengan terjadinya suatu tindak pidana tersebut. Jadi kalau tanpa motif itu, sulit untuk menduga dalam diri si pelaku ada niat atau mens rea tadi. Karena mes rea ini sangat abstrak ada dalam benak seseorang. Secara psikologis kita tidak bisa mengetahui apa yang terjadi di balik kepala seseorang. Tetapi kalau perbuatan itu terjadi dan terbukti dia memperoleh keuntungan dari situ. Jadi motif itu sudah dibuahi menjadi suatu kehendak. Yang kemudian ditunaikan dalam suatu tindak pidana. Dapat disimpulkan bahwa seseorang memiliki motif, berupa kehendak yang ditunaikan dalam perbuatannya. $^{12}$

Dengan dikeluarkannya uang negara atau APBD propinsi untuk pengadaan tanah TPU kota maka tanggung jawab untuk melakukan evaluasi atau telaah dapat diartikan sebagai bagian kelalaian dan tidak bisa dilimpahkan begitu saja kepada ketua walikota $e x$ officio yang pada saat itu dalam situasi darurat sipil melaksanakan tugas sebagai unsur pelaksanaan darurat sipil di kota maka pekerjaanpekerjaan rutin administrasi kepemeritahan seperti pekerjaan memimpin rapat-rapat $\mathrm{P} 2 \mathrm{~T}$ di delegasikan kepada panitia lainnya dengan pertimbangan-pertimbangan yang ada, dan hasil kerja P2T dikoordinasikan dengan wakil ketua dan panitia lainnya. Kemudian tanggung jawab pengawasannya untuk proyek pemba-

\footnotetext{
${ }^{12}$ Hasil wawancara dengan informan Ahli Hukum Pidana, Jakarta 30 September 2013.
}

ngunan TPU yang terbengkalai masih harus melalui waktu yang cukup panjang dengan adanya keterbatasan waktu yang sudah diterima sebelumnya dari tim yang ditunjuk itu tentunya ketua walikota ex-officio tidak bisa begitu saja dipersalahkan atas kelalaian kepala daerah yang ada padanya.

Terkait dengan pertanggung jawaban pidana apakah dengan kelalaian yang dilakukan oleh anggota P2T Kotamadya apakah bisa dipertanggung jawabkan kepada ketua walikota ex-officio jika dikaitkan dengan pasal 55 KUHP, untuk itu terkait pasal ini harus dinyatakan dahulu apakah betul tindak pidana itu telah terjadi : siapa pelaku, apa bentuk kesalahannya barulah dapat menentukan apakah P2T bersama ketua panitia turut serta melakukan sebab tentunya tidak bisa dengan gegabah menyatakan bahwa terjadi turut serta melakukan oleh sebab itu harus dilihat dahulu sikap batinnya apakah memang ada sikap batin jahat pada pelaku maupun yang turut serta melakukan itu, sikap batin jahat itu kalau ditinjau dari hukum pidana harus ada motif. Dengan adanya motif yang ada pada diri pelaku kemudian menimbulkan rangsangan motif disini apakah dapat dikatakan sebagai kelalaian. Tentunya harus dibedakan antara motif dan kelalaian kalau itu berupa kelalaian (culpa) tentunya tidak bisa dipersamakan dengan dolus atau kesengajaan dalam berbagai bentuknya. Kalau itu berupa kelalaian saja tidak bisa dikatakan bahwa ketua walikota ex-officio mempunyai kehendak sampai terjadinya akibat suatu motif yang dibuai oleh perbuatannya. Selain itu cara penerapan tanggung jawab pidana dalam jabatan harus ditelaah dahulu pertanggung jawabannya dalam arti apakah terbentuk adanya kehendak atau melalaikan dengan sengaja atau ada alasan pembenaran dalam melakukan tindakan yang bersangkutan, oleh karena itu berkaitan dengan pasal 55 KUHP tentunya harus dilihat sebagai satu kesatuan yang utuh sebab disitulah akan dilihat bagaimana kehendak, bagaimana kerjasama tersebut terjadi dan bagaimana kesadaran masing-masing pihak baik sebagai pelaku maupun turut serta melakukan. Akan tetapi jika hanya salah satu yang terkena dalam artian yang turut serta melakukan ternyata tidak memiliki kehendak atau sikap batin jahat.Tentunya tidak bisa menyeret begitu saja 
dalam hal turut serta melakukan perbuatan tersebut.

Timbul pertanyaan apabila ternyata tindak pidananya tidak terbukti apakah yang turut serta melakukan perbuatan ini tetap bisa di pidana atau apabila turut serta perbuatan ini tidak di pidana apakah yang melakukan juga tidak harus di pidana? dalam hal demikian berarti pelakunya tidak bisa dikaitkan dengan penyertaan tindak pidana sebab yang melakukan hanya satu karena, yang diduga turut serta melakukan ketika diperiksa kesalahannya tidak terbukti maka tentunya tidak bisa menyeret yang bersangkutan begitu saja untuk masuk dalam tindak pidana. Jika dikaitkan dengan prinsip pengadaan tanah untuk kepentingan umum yang tidak digunakan untuk mencari keuntungan maka bagaimana bisa dipersalahkan bahwa dia telah sengaja memberikan peluang tindak pidana korupsi ? untuk itu dikatakan memberikan peluang tapi kembali kepada apa motif yang ada dibalik memberi peluang tadi, apakah memang itu berhubungan dengan adanya motif untuk kemudian memperoleh keuntungan di kemudian hari bagi yang bersangkutan. Sebab pada pidana umum atau tindak pidana korupsi harus ada motif mutlak adanya. $^{13}$

Jika dalam tindak pidana korupsi ternyata kelalaian seseorang itu apakah dapat dihukum? tentu dalam merespon hal ini kalau yang bersangkutan dipersalahkan juga ini berarti bahwa kelalaian dapat di pidana dalam hal tindak pidana korupsi. Padahal unsur sikap batin jahat dengan kehendak atau niat kesengajaan tersebut harus bersinergi. Oleh sebab itu bisa dibandingkan dengan kasus Akbar Tandjung apakah dalam diri Akbar Tandjung ternyata ada motif? sehingga ketika pemeriksaan pada diri Akbar Tandjung tidak terdapat motif yang ditujukan kepada beliau maka beliau tidak bisa dipersalahkan atas terjadinya akibat tersebut. Dengan adanya motif ini apakah bisa dimaksudkan untuk menguntungkan orang lain ? pada dasarnya motif dimaksud ini harus dilihat untuk diri sendiri juga walaupun bisa saja dalam hal-hal tertentu motif tersebut berkaitan dengan kepentingan orang lain, namun motif tersebut harus diuji apakah betul dengan adanya pemberian keleluasaan ketua walikota $e x-$

\footnotetext{
${ }^{13}$ Ibid
}

officio kepada panitia lainnya sehingga muncul perbuatan tersebut sebagai suatu tindak pidana harus dilihat apakah memang ada motif untuk menguntungkan orang lain perlu ada konstruksi ulang kerugian Negara tersebut.

Terkait dengan dugaan tindak pidana korupsi dalam pengadaan tanah untuk kepentingan umum (TPU) Kotamadya maka teori Leonard J. Theberge bahwa faktor utama bagi hukum untuk dapat berperanan pembangunan ekonomi (pembangunan untuk kepentingan umum) adalah apakah hukum mampu menciptakan "stability", "predictability" dan "fairness". 14

Stability berarti hukum dapat mengakomodir atau menyeimbangkan kepentingan-kepentingan yang bersaing dalam masyarakat. Predictability berarti bahwa hukum dapat membawa kepastian. Masyarakat dari awal bisa memperkirakan dari mula hukum akan melindungi hak-haknya dan membayangkan juga apa akibat dari langkah-langkah yang dilakukan. Selanjutnya fairness hukum harus melahirkan keadilan, memberikan kepastian mana yang benar dan yang salah. Tidak adanya keadilan dalam jangka panjang dapat mengakibatkan Pemerintah kehilangan legitimasi.

Dalam hubungannya dengan pengadaan tanah untuk kepentingan umum (TPU) Kotamadya, hukum penting untuk menciptakan ketiga kualitas yang dimaksud oleh Leonard J. Theberge baik Pemerintah yang memerlukan tanah maupun pemilik tanah tempat dimana proyek pembangunan (TPU) Kotamadya akan dibangun harus mendapat kepastian akan usaha dan hak. Hukum juga harus mengakomodir dan mengimbangkan kepentingan pemerintah yang harus membangun prasarana TPU dan hak pemilik tanah yang akan diambil sehingga hukum ini berlaku adil kepada kedua belah pihak.

\section{Kesimpulan}

1. tanggung jawab panitia pengadaan tanah (P2T) untuk kepentingan umum (TPU) di Kotamadya berakhir setelah terjadi pelepasan tanah dan pembebasan tanah atau penyerahan hak dari pemegang hak atas tanah dengan pemberian ganti kerugian. Ke-

\footnotetext{
${ }^{14}$ Leonardo J. Theberge, "Law and Economic Development", Journal International Law and Politic, vol. 9 (1980) hal. 232.
} 
mudian dilanjutkan dengan membuat berita acara ganti kerugian dengan disaksikan seluruh anggota P2T, selanjutnya diserahkan kepada instansi yang memerlukan tanah setelah itu tanggung jawab beralih kepada Instansi yang memerlukan tanah untuk melakukan penguasaan dan pemeliharaan tanah.

2. Dugaan tindak pidana korupsi berupa kerugian keuangan Negara pada waktu penguasaan, pengurusan tanah oleh Walikota pada saat dan dalam keadaan dalam darurat sipil di provinsi tentunya tidak bisa dikatakan melakukan tindak pidana korupsi.

\section{Saran}

1. Perlu ada konstruksi ulang kekerugianan Negara dalam pengadaan tanah untuk kepentingan umum pembangunan (TPU) Kotamadya mengingat pencatatan tanah (TPU) Gunung Nona sudah dimasukan dalam daftar asset daerah tahun 2014.

2. Perlu penegakan hukum yang objektif dengan mentaati peraturan perundang-undangan yang berlaku, khususnya aturan-aturan mengenai pengadaan tanah. 


\section{Daftar Pustaka}

\section{Buku}

Arie S. Hutagalung, “Tebaran Pemikiran Seputar Masalah Hukum Tanah” Jakarta: LPHI 2005.

Gunanegara, rakyat dan negara dalam pengadaan tanah untuk pembangunan, Jakarta: Tata Nusa, 2008, Cetakan Pertama.

Maria S.W. Sumardjono, Tanah dalam perspektif hak ekonomi, sosial, budaya. Jakarta: Kompas, 2008, Cetakan Pertama.

R. Wiyono, Pembahasan Undang-Undang RIPemberantasan Tindak Pidana Korupsi, Jakarta:

Sinar Grafika, 2005.

\section{Makalah}

Arie S. Hutagalung, “Analisis Yuridis Keputusan Presiden” Nomor 55 Tahun 1993.

Maria S.W. Sumardjono, "Tinjauan Yuridis Keppres No. 55 tahun 1993 tentang pengadaan tanah bagi pelaksanaan pembangunan untuk kepentingan umum dan pelaksanaannya".

------, “Aspek kepentingan umum dalam kaitannya dengan pengadaan tanah".

\section{Jurnal}

Journal International Law and Politic vol. 9 (1980).

Leonardo J. Theberge, "Law and Economic Development", Journal International Law and Politic vol. 9 (1980).

\section{Surat Kabar}

Aartje Tehupeinory, “Pembebasan Tanah KBT”, Suara Pembaruan, 29 Desember 2009.

\section{Peraturan Perundang-Undangan}

Undang-Undang RI Dasar 1945.

Undang-Undang RI Nomor 5 Tahun 1960 Tentang Peraturan Dasar Pokok-Pokok Agraria (UUPA) Keputusan Presiden Nomor 55 Tahun 1993 Tentang Pengadaan Tanah bagi Pelaksanaan Pembangunan Untuk Kepentingan Umum.

Undang-Undang RI Nomor 31 Tahun 1999 tentang Pemberantasan Tindak Pidana Korupsi.

Undang-Undang RI Nomor 20 Tahun 2001 tentang Perubahan Atas Undang-Undang RINomor 31 Tahun 1999 tentang Pemberantasan Tindak Pidana Korupsi 